Phinisi Integration Review
Vol. 2, No.2, Agustus 2019 Hal 302-312
Website: $\underline{\text { http://ojs.unm.ac.id/pir }}$
p-ISSN: 2614-2325 dan e-ISSN: 2614-2317
DOI: https://doi.org/10.26858/pir.v2i2.10048

\title{
Hubungan Lingkungan Sosial Sekolah dan Tingkat Pendidikan Orang Tua dengan Prestasi Belajar IPS Peserta Didik
}

\author{
Nurul Muawiah Mujahiduddin \\ Pendidikan IPS, Kekhususan IPS Ke-SD-an, Program Pascasarjana, Universitas Negeri Makassar \\ Email: nurulmuawiah@yahoo.com
}

\begin{abstract}
Abstrak. Penelitian ini bertujuan untuk mengetahui 1) Hubungan lingkungan sosial sekolah dengan prestasi belajar IPS peserta didik, 2) Hubungan tingkat pendidikan orang tua dengan prestasi belajar IPS peserta didik, dan 3) Hubungan lingkungan sosial sekolah dan tingkat pendidikan orang tua dengan prestasi belajar IPS peserta didik. Penelitian ini menggunakan pendekatan kuantitatif deskriptif. Sampel dalam penelitian ini adalah peserta didik kelas IV, V dan VI berjumlah 65 orang peserta didik dan 65 orang tua. Teknik pengambilan sampel adalah dengan teknik Purposive Sampling dengan kriteria peserta didik yang nilai prestasinya dalam kategori rendah, sedang, dan kategori tinggi. Data penelitian ini dikumpulkan melalui observasi, wawancara, dan dokumentasi. Hasil penelitian menunjukkan bahwa pertama, terdapat hubungan yang signifikan antara lingkungan sosial sekolah dengan prestasi belajar IPS peserta didik yang ditunjukkan dengan koefisien korelasi $\mathrm{rx}_{1} \mathrm{y}$ sebesar 0,730 . Kedua, tidak terdapat hubungan yang signifikan antara tingkat pendidikan orang tua dengan prestasi belajar IPS peserta didik yang ditunjukkan dengan koefisien korelasi $\mathrm{rx}_{2} \mathrm{y}$ sebesar $-0,272$. Ketiga, terdapat hubungan yang signifikan antara lingkungan sosial sekolah dan tingkat pendidikan orang tua dengan prestasi belajar IPS peserta didik yang ditunjukkan dengan koefisien korelasi 0,756 dan secara simultan ada $57,2 \%$ kontribusi lingkungan sosial sekolah dan tingkat pendidikan orang tua dengan prestasi belajar IPS peserta didik SD Negeri 2 Parepare.
\end{abstract}

Kata Kunci: prestasi belajar, lingkungan sosial sekolah, tingkat pendidikan orang tua

\begin{abstract}
This study aims to know: 1) The relationship between school social environment with learning social achievement of students. 2) The relationship between parent's education levels with learning social achievement of students, and 3) The relationship is between school social environment and parent's education levels with learning social achievement of students. This research used quantitative approach. Sample of this research was the students in IV, V, and VI students at Elementary School 2 Parepare. There are 65 students and 65 parents. The sampling technique used probability technique or from the sample took as the categorized for students are low and high categories. The research is collected by using observation, interview, and documentation. The result of this research showed that firstly, there was significant relationship between school social environments with learning social achievement of students. It is shown by correlation coefficient rx $1 \mathrm{y}$ that is 0,730 . Secondly, there was not significant relationship between parent's education levels with learning social achievement of students. It is shown by correlation coefficient $\mathrm{rx} 2 \mathrm{y}$ that is $-0,272$. Thirdly, there was significant relationship between school social environment and parent's education levels with learning social achievement of students. It is shown by correlation coefficient (R) is 0,756 and that simultaneously there are $57.2 \%$ of the relationship between school social environment and parent's education levels with learning social achievement of students at Elementary School 2 Parepare.
\end{abstract}

Keywords: learning achievement, school social environment, parent's education levels 


\section{PENDAHULAN}

Pendidikan merupakan model rekaya sosial yang paling efektif untuk menyiapkan suatu bentuk masyarakat masa depan. Masa depan suatu masyarakat akan ditentukan oleh konsep dan penyelenggara pendidikan. Jika pendidikan dilihat sebagai suatu sistem, maka akan ada sub-sub sistem yang secara teratur saling berkaitan sehingga membentuk totalitas dalam pencapaian tujuan pendidikan.

Pendidikan berlangsung dalam suatu proses panjang yang pada akhirnya adalah untuk mencapai tujuan, di antaranya memiliki prestasi yang tinggi dalam segala bidang serta pribadi yang dewasa susila. Salah satu faktor eksternal yang mempengaruhi prestasi belajar peserta didik adalah faktor lingkungan sosial. Lingkungan sosial kedua, yaitu lingkungan sekolah adalah lingkungan pendidikan formal yang mempunyai peran penting dalam mencerdaskan dan membimbing moral perilaku anak serta bertanggung jawab menghasilkan sumber daya manusia yang berkualitas. Lingkungan sekolah digolongkan sebagai pusat pendidikan kedua setelah keluarga sehingga mempunyai fungsi melanjutkan pendidikan keluarga dengan guru sebagai pengganti orang tua yang harus ditaati.

Suasana lingkungan sosial sekolah yang kondusif akan mempengaruhi aktivitas belajar peserta didik dan berdampak positif terhadap prestasi belajar peserta didik. Begitu pula sebaliknya kecenderungan lingkungan sosial peserta didik yang kurang baik mempunyai dampak negatif terhadap prestasi belajar peserta didik. Lingkungan sosial sekolah merupakan lingkungan pergaulan antar manusia, pergaulan antara pendidik dengan peserta didik serta orangorang lainnya yang terlibat dalam interaksi pendidikan. Interaksi pendidikan dipengaruhi karakteristik pribadi dan corak pergaulan antar orang-orang yang terlibat dalam interaksi tersebut, baik pihak peserta didik maupun para pendidik (guru) dan pihak lainnya. Tiap orang memiliki karakteristik pribadi masing-masing, sebagai individu maupun sebagai anggota kelompok (Sukmadinata, 2007:5).

Sebelum peserta didik menginjakkan kakinya di lembaga pendidikan formal, peserta didik tentu berada pada lingkungan yang paling dekat dengannya, yaitu keluarga. Pendidikan dalam lingkungan keluarga akan tertanam sejak usia muda yang semakin lama semakin menyatu dalam diri seorang anak dengan bertambahnya usia mereka. Faktor orang tua sangat besar pengaruhnya terhadap keberhasilan anak dalam belajar dan kemampuan mendidik orang tua sekiranya dipengaruhi dari tingkat pendidikan yang dimilikinya.

Orang tua yang memiliki tingkat pendidikan tinggi biasanya memiliki cita-cita atau harapan yang tinggi terhadap pendidikan anak-anaknya. Mereka menginginkan agar pendidikan anak-anaknya lebih tinggi atau setidaknya setara dengan pendidikan terakhir orang tua mereka. Cita-cita dan dorongan ini diharapkan mampu memengaruhi sikap dan keberhasilan anak-anaknya di sekolah. Tingkat pendidikan orang tua akan memotivasi mereka untuk menyekolahkan dan memerhatikan pendidikan anak-anaknya agar mampu bersaing di zamannya kelak dan memiliki prestasi belajar yang baik. Menurut Tu'u (2004:75), prestasi belajar adalah penguasaan pengetahuan atau keterampilan yang dikembangkan oleh mata pelajaran, lazimnya ditunjukkan dengan nilai tes atau angka nilai yang diberikan oleh guru.

Orang tua yang mempunyai tingkat pendidikan yang tinggi akan lebih percaya diri dalam memberikan bantuan pembelajaran dari sekolah kepada anaknya saat belajar sehingga peran orang tua tidak hanya sekadar memberikan uang jajan atau menyekolahkan mereka, tetapi juga ikut berperan dalam proses pendidikan anaknya. Perlakuan orang tua dapat menyebabkan baik tidaknya perilaku seorang anak. Kesibukan dan ketidakmengertian orang tua akan berakibat kurangnya waktu dalam membersamai dan mendidik anak mereka agar memiliki akhlak mulia. Begitu pula sebaliknya, perhatian dan pengarahan orang tua kepada anak dapat membangun kemampuan anak bersikap, bertindak cerdas, arif, dan bertanggung jawab dalam kehidupannya sehari-hari sehingga anak akan siap menghadapi tuntutan perubahan di masa yang akan datang.

Hal tersebut sejalan dengan tujuan pembelajaran IPS di SD, menurut Nursid Sumaatmadja (1984) dalam Hidayati (2008:21) "Tujuan pembelajaran IPS adalah membina anak didik menjadi warga negara yang baik yang memiliki pengetahuan, keterampilan, dan 
kepedulian sosial yang berguna bagi dirinya serta bagi masyarakat dan negara." Selain hal tersebut pengorganisasian materi pembelajaran di sekolah dasar berbeda dengan pengorganisasian materi pembelajaran di tingkat menengah dan atas. Menurut Sapriya (2017:56) "Pengorganisasian materi mata pelajaran IPS menganut pendekatan terpadu (integrated), artinya mata pelajaran dikembangkan dan disusun tidak mengacu pada disiplin ilmu yang terpisah melainkan mengacu pada aspek kehidupan nyata (factual/real) peserta didik."

Sekolah Dasar Negeri 2 Parepare merupakan salah satu sekolah dasar yang berada di kecamatan Soreang Kota Parepare dengan menyelenggarakan dan menampung peserta didik yang memiliki variasi pada tingkat pendidikan orang tua peserta didik. Hal tersebut diketahui dari hasil pengamatan sementara peneliti dan pengakuan dari kepala sekolah yang didampingi oleh staf tata usaha dan operator dapodik SD Negeri 2 Parepare. Selain dari uraian tersebut, peneliti juga menemukan adanya fenomena yang terlihat dari hasil observasi dua tahun terakhir di setiap akhir semester bahwa anak-anak yang berprestasi dalam hal akademik dilihat dari nilai harian dan buku rapor (kognitif, psikomotorik, dan afektif) memiliki latar belakang pendidikan orang tua yang tidak semuanya berakhir di pendidikan tinggi, tetapi ada juga sebagian peserta didik yang orang tuanya hanya sampai pada pendidikan dasar mampu berprestasi seperti teman-temannya yang memiliki orang tua yang berakhir di pendidikan tinggi. Melalui fenomena tersebut terlihat bahwa orang tua yang memiliki tingkat pendidikan tinggi tidak selamanya mampu membimbing anaknya belajar dan berprestasi di sekolahnya dan begitu pula sebaliknya (Observasi 12 November 2018).

Setelah dicermati, kondisi tersebut tidak terlepas dari adanya pengaruh lingkungan sosial sekolah yang berperan penting dalam membantu peserta didik dalam berinteraksi dengan berbagai sumber daya pendidikan. Berdasarkan hasil pengamatan sementara di SD Negeri 2 Parepare terlihat kurang harmonisnya interaksi antarpeserta didik, hal tersebut terlihat dari beberapa bentuk peilaku bullying misalnya saling mengejek, memukul dan menendang temannya, bahkan beberapa ada yang merusak barang temannya sehingga timbul pertengkaran dan adanya persaingan antarkelompok peserta didik. Selain itu, di dalam proses pembelajaran terlihat interaksi antara guru dengan peserta didik yang belum maksimal, ditandai dengan adanya peserta didik yang kurang memerhatikan guru pada saat pembelajaran berlangsung. Secara tidak langsung, hal-hal tersebut akan memberikan pengaruh terhadap prestasi belajar IPS peserta didik. (Observasi 13 November 2018).

Berdasarkan pandangan terhadap masalah-masalah yang telah diuraikan sebelumnya maka dipandang perlu melakukan kajian mendalam dengan penyusunan tesis berjudul Hubungan Lingkungan Sosial Sekolah dan Tingkat Pendidikan Orang Tua dengan Prestasi Belajar IPS Peserta Didik SD Negeri 2 Parepare.

\section{METODE PENELITIAN}

Pendekatan yang digunakan dalam penelitian ini adalah pendekatan kuantitatif. Metode penelitian deskriptif analitis dalam penelitian ini digunakan untuk menggambarkan karakteristik sesuatu sebagaimana adanya saat penelitian dilaksanakan dengan tujuan untuk mencari informasi faktual yang mendetail (menggambarkan) hubungan lingkungan sosial sekolah dan tingkat pendidikan orang tua dengan prestasi belajar IPS peserta didik SD Negeri 2 Parepare.

Penelitian ini menggunakan jenis penelitian expost facto dengan pendekatan korelasional, yaitu penelitian yang bertujuan untuk mengetahui tingkat hubungan antara variabel lingkungan sosial sekolah dan variabel tingkat pendidikan orang tua dengan variabel prestasi belajar IPS tanpa ada upaya untuk memengaruhi variabel tersebut sehingga tidak terdapat manipulasi variabel.

Penelitian ini terdiri atas tiga variabel, dua variabel bebas (independent) dan satu variabel terikat (dependent). Variabel bebas adalah variabel yang memengaruhi atau memiliki hubungan terhadap variabel terikat, yaitu lingkungan sosial sekolah (X1) dan tingkat pendidikan orang tua (X2) sedangkan variabel terikat, yaitu prestasi belajar IPS (Y).

Lingkungan sosial sekolah yang dimaksud merupakan skor/nilai yang diperoleh melalui observasi dengan skala bertingkat terhadap keseluruhan komponen yang terdapat di sekitar lingkungan sosial sekolah, seperti interaksi guru dengan peserta didik dan interaksi antar peserta didik.

Tingkat pendidikan orang tua yang dimaksud adalah nilai/skor tingkat pendidikan orang tua/wali peserta didik, yaitu dari Pendidikan Dasar (SD/MI, SMP/MTs); 
Pendidikan Menengah (SMA dan MA, SMK dan MAK); dan Pendidikan tinggi (Akademi, Institut, Sekolah Tinggi, Universitas). Untuk memperoleh data tentang tingkat pendidikan orang tua dilakukan dengan menggunakan wawancara terstruktur.

Prestasi belajar IPS yang dimaksud adalah nilai/skor yang diperoleh dari hasil belajar yang dicapai oleh peserta didik selama mengikuti pembelajaran pada suatu periode tertentu, yaitu diukur dari nilai Penilaian Harian (PH), Penilaian Tengah Semester (PTS), dan Penilaian Akhir Semester (PAS) semester ganjil tahun ajaran 2018/2019.

Populasi dalam penelitian ini adalah seluruh peserta didik, orang tua peserta didik, dan guru kelas IV, V, dan VI di SD Negeri 2 Parepare yang berjumlah 80 orang, orang tua peserta didik berjumlah 80 orang, dan guru kelas berjumlah 3 orang. Penentuan ukuran sampel mengacu pada Rumus Isaac dan Michel untuk tingkat kesalahan $5 \%$.

Teknik pengumpulan data yang digunakan peneliti dalam penelitian ini adalah

Observasi yang digunakan dalam penelitian ini, yaitu dengan melengkapi lembar pengamatan sebagai instrumen pertimbangan dalam penelitian. Format yang tersusun tersebut berisi item-item tentang kejadian atau tingkah laku yang digambarkan dalam proses pembelajaran di kelas. Peneliti mengadakan penilaian dengan skala bertingkat.

Wawancara yang digunakan dalam penelitian ini adalah wawancara terstruktur. Dalam melakukan wawancara, peneliti telah menyiapkan instrumen penelitian berupa pertanyaan-pertanyaan tertulis yang alternatif jawabannya pun sudah disiapkan oleh peneliti.

Dokumentasi diperlukan sebagai metode pendukung untuk mengumpulkan data karena dalam metode ini dapat diperoleh data-data historis seperti visi dan misi sekolah, daftar guru dan tenaga pendidik, daftar nama peserta didik, dan dokumen yang menunjukkan keadaan prestasi belajar IPS peserta didik kelas IV s.d VI di SD Negeri 2 Parepare yang sudah menjadi sampel penelitian.

Instrumen pedoman observasi (lembar pengamatan) tersebut diisi oleh peneliti sebagai observer yang terbagi atas dua lembar pengamatan, yaitu lembar pengamatan interaksi guru dengan peserta didik dan lembar pengamatan interaksi antar peserta didik.

Pedoman wawancara dalam penelitian ini berisi informasi tentang hubungan tingkat pendidikan orang tua dengan prestasi belajar IPS peserta didik SD Negeri 2 Parepare. Data yang diperoleh dari pedoman wawancara adalah data kuantitatif yang selanjutnya digunakan untuk menguji hipotesis dengan menggunakan perhitungan rata-rata lamanya orang tua peserta didik menempuh pendidikan.

Analisis statistik deskriptif dilakukan untuk menggambarkan kondisi masing-masing variabel dengan bantuan program IBM SPSS Statistics 25. Menghitung central tendency (gejala pusat), yang meliputi mean, median, modus, dan standar deviasi serta melakukan pengkategorian hasil penelitian.

Uji Normalitas Data. Uji normalitas digunakan untuk melihat apakah data berdistribusi normal atau tidak. Analisis parametrik seperti regresi linear mensyaratkan bahwa data harus berdistribusi normal.

Uji Linearitas Data. Uji linieritas digunakan untuk mengetahui linearitas data, yaitu apakah dua variabel mempunyai hubungan yang yang linear atau tidak. Hubungan yang linier ditandai dengan adanya kenaikan skor pada suatu variabel diikuti kenaikan pula pada variabel lainnya.

Uji Multikolinearitas Data. Uji Multikolinearitas digunakan untuk menguji apakah dalam model regresi ditemukan adanya korelasi antara variabel bebas (independen).

Analisis korelasi digunakan untuk mencari arah dan kuatnya hubungan antara dua variabel atau lebih, baik hubungan yang bersifat simetris, kausal, dan reciprocal. Regresi Linier Berganda digunakan untuk mengetahui pengaruh dari variabel bebas terhadap variabel terikat. Koefisien determinasi $\left(\mathrm{R}^{2}\right)$ digunakan untuk mengetahui besarnya persentase kontrbusi variabel bebas terhadap variabel terikat yang dilakukan dengan cara menghitung koefisien determinasi.

Uji regresi linear sederhana digunakan untuk mengetahui hubungan lingkungan sosial sekolah dan tingkat pendidikan orang tua secara parsial/terpisah dengan prestasi belajar IPS Peserta Didik SD Negeri 2 Parepare (Uji t).

Uji regresi berganda digunakan untuk mengetahui hubungan lingkungan sosial sekolah (X1) dan tingkat pendidikan orang tua (X2) secara simultan/bersama-sama dengan prestasi belajar IPS (Y) peserta didik SD Negeri 2 Parepare (uji F). 


\section{HASIL DAN PEMBAHASAN}

Penelitian hubungan lingkungan sosial sekolah dan tingkat pendidikan orang tua dengan prestasi belajar IPS peserta didik SD Negeri 2 Parepare telah dilaksanakan dari bulan Februari sampai dengan Maret 2019. Lokasi penelitian berada di Jalan Abu Bakar Lambogo No. 7 Kelurahan Ujung Lare Kecamatan Soreang Kota Parepare Provinsi Sulawesi Selatan.

\section{Hasil Analisis Deskriptif Prestasi Belajar IPS}

Berdasarkan data penelitian yang diolah menggunakan bantuan komputer program IBM SPSS Statistics 25 untuk Prestasi Belajar IPS skor terendah yang dicapai adalah 74 dan skor tertinggi adalah 95 dari data tersebut diperoleh harga rerata (mean) sebesar 84,32, nilai tengah (median) sebesar 85,00, modus (mode) sebesar 85, dan standar deviasi sebesar 5,764. Distribusi frekuensi variabel prestasi belajar IPS dapat dilihat pada tabel 1.1.

Tabel 1.1 Data Responden untuk Variabel Prestasi Belajar IPS Peserta Didik SDN 2 Parepare

\begin{tabular}{cccc}
\hline Kategori & Rentang Skor & F & $\begin{array}{c}\mathbf{F} \\
(\mathbf{\%})\end{array}$ \\
\hline Sangat Rendah & $Y \leq 70,5$ & 0 & 0 \\
Rendah & $70,5<Y \leq 77$ & 12 & 18,46 \\
Sedang & $77<Y \leq 85,5$ & 25 & 38,46 \\
Tinggi & $85,5<Y \leq 93$ & 24 & 36,92 \\
Sangat Tinggi & $93<Y$ & 4 & 6,15 \\
\hline & Jumlah & 65 & 100 \\
\hline
\end{tabular}

Sumber: Hasil Pengolahan Data Penelitian

Berdasarkan kategorisasi yang dilakukan diketahui bahwa prestasi belajar IPS masuk dalam kategori sangat tinggi sebanyak 4 orang $(6,15 \%)$, tinggi sebanyak 24 orang $(36,92 \%)$, sedang sebanyak 25 orang $(38,46 \%)$, rendah sebanyak 12 orang $(18,46 \%)$, dan sangat rendah sebanyak $0(0 \%)$. Dari persentase tersebut dapat disimpulkan bahwa prestasi belajar IPS termasuk dalam kategori sedang.

\section{Hasil Analisis Deskriptif Lingkungan Sosial Sekolah}

Berdasarkan data penelitian yang diolah menggunakan bantuan komputer program IBM SPSS Statistics 25 untuk lingkungan sosial sekolah skor terendah yang dicapai adalah 150 dan skor tertinggi adalah 230 dari data tersebut diperoleh harga rerata (mean) sebesar 200,66, nilai tengah (median) sebesar 202,00, modus (mode) sebesar 194, dan standar deviasi sebesar 16,548. Distribusi frekuensi variabel lingkungan sosial sekolah dapat dilihat pada tabel 1.2.
Tabel 1.2 Data Responden untuk Variabel Lingkungan Sosial Sekolah SDN 2 Parepare

\begin{tabular}{cccc}
\hline Kategori & Rentang Skor & F & F (\%) \\
\hline Sangat Rendah & $X_{1} \leq 110$ & 0 & 0 \\
Rendah & $110<X_{1} \leq 147$ & 0 & 0 \\
Sedang & $147<X_{1} \leq 183$ & 7 & 10,77 \\
Tinggi & $183<X_{1} \leq 220$ & 53 & 81,54 \\
Sangat Tinggi & $220<X_{1}$ & 5 & 7,69 \\
\hline & Jumlah & 65 & 100 \\
\hline
\end{tabular}

Sumber: Hasil Pengolahan Data Penelitian

Berdasarkan pada tabel 1.2 dapat dilihat bahwa dari seluruh indikator variabel lingkungan sosial sekolah yang diamati menunjukkan bahwa pada kategori sangat tinggi sebanyak 5 orang $(7,69 \%)$, tinggi sebanyak 53 orang $(81,54 \%)$, sedang sebanyak 7 orang $(10,77 \%)$, rendah sebanyak $0(0 \%)$, dan sangat rendah sebanyak 0 $(0 \%)$. Dari persentase tersebut dapat disimpulkan bahwa lingkungan sosial sekolah termasuk dalam kategori tinggi.

\section{Hasil Analisis Deskriptif Tingkat Pendidikan Orang Tua}

Berdasarkan data penelitian yang diolah menggunakan bantuan komputer program IBM SPSS Statistics 25 untuk tingkat pendidikan orang tua skor terendah yang dicapai adalah 5 dan skor tertinggi adalah 17 dari data tersebut diperoleh harga rerata (mean) sebesar 12,36, nilai tengah (median) sebesar 12,00, modus (mode) sebesar 16, dan standar deviasi sebesar 2,998. Distribusi frekuensi variabel tingkat pendidikan orang tua dapat dilihat pada tabel 1.3.

Tabel 1.3. Data Responden untuk Variabel Tingkat Pendidikan Orang Tua Peserta Didik SDN 2 Parepare

\begin{tabular}{cccc}
\hline Kategori & Rentang Skor & F & $\begin{array}{c}\mathbf{F} \\
(\mathbf{\%})\end{array}$ \\
\hline Sangat Rendah & $X_{2} \leq 5,25$ & 1 & 1,54 \\
Rendah & $5,25<X_{2} \leq 8,75$ & 6 & 9,23 \\
Sedang & $8,75<X_{2} \leq 12,25$ & 27 & 41,54 \\
Tinggi & $12,25<X_{2} \leq 15,75$ & 17 & 26,15 \\
Sangat Tinggi & $15,75<X_{2}$ & 14 & 21,54 \\
\hline & Jumlah & 65 & 100 \\
\hline
\end{tabular}

Sumber: Hasil Pengolahan Data Penelitian

Berdasarkan kategorisasi yang dilakukan diketahui bahwa tingkat pendidikan orang tua masuk dalam kategori sangat tinggi sebanyak 14 orang $(21,54 \%)$, tinggi sebanyak 17 orang $(26,15 \%)$, sedang sebanyak 27 orang $(41,54 \%)$, rendah sebanyak 6 orang $(9,23 \%)$, dan sangat rendah sebanyak 1 orang $(1,54 \%)$. Dari persentase tersebut dapat disimpulkan bahwa 
tingkat pendidikan orang tua peserta didik termasuk dalam kategori sedang.

\section{Uji Normalitas Data}

Berdasarkan data penelitian yang diolah menggunakan bantuan komputer program IBM SPSS Statistics 25 menunjukkan bahwa nilai signifikasi pada Asymp. Sig. masing-masing variabel, yaitu variabel lingkungan sosial sekolah (X1) sebesar $0,090>0,05$, variabel tingkat pendidikan orang tua (X2) sebesar 0,084 >0,05, dan prestasi belajar IPS (Y) sebesar 0,100 >0,05. Masing-masing variabel memiliki nilai signifikasi lebih besar dari 0,05 sehingga dapat disimpulkan bahwa ketiga variabel yaitu tersebut berdistribusi normal.

\section{Uji Linearitas Data}

Berdasarkan data penelitian yang diolah menggunakan bantuan komputer program IBM SPSS Statistics 25 diperoleh nilai signifikansi pada Deviation from Linierity pada tabel anova untuk variabel lingkungan sosial sekolah dan prestasi belajar IPS sebesar 0,148. Karena signifikansi lebih dari 0,05 maka dapat disimpulkan bahwa antara variabel lingkungan sosial sekolah dan prestasi belajar IPS berjalan linier. Sedangkan diperoleh nilai signifikansi pada Deviation from Linierity pada tabel anova untuk variabel tingkat pendidikan orang tua dan prestasi belajar IPS sebesar 0,814. Karena signifikansi lebih dari 0,05 maka dapat ditarik kesimpulan bahwa antara variabel tingkat pendidikan orang tua dan prestasi belajar IPS berjalan linier. Dengan demikian, dapat disimpulkan bahwa terdapat pengaruh yang linear signifikan antara variabel bebas dengan variabel terikat.

\section{Uji Multikolinearitas Data}

Uji multikolinieritas dilakukan dengan menggunakan bantuan program IBM SPSS Statistics 25 dan berdasarkan analisis pada uji data penelitian diperoleh pada bagian Collinearity Statistics diketahui nilai Tolerance untuk variabel Lingkungan Sosial Sekolah (X1) dan Tingkat Pendidikan Orang Tua (X2) adalah $0,990>0,10$. Sementara nilai VIF untuk variabel Lingkungan Sosial Sekolah (X1) dan Tingkat Pendidikan Orang Tua (X2) adalah 1,010 < 10,00. Mengacu pada dasar pengambilan keputusan dalam uji multikolinearitas dapat disimpulkan bahwa tidak terjadi gejala multikolinearitas.
7. Uji Hipotesis

a. Korelasi Pearson Product Moment

1) Pengujian Hipotesis Pertama

Berdasarkan hasil analisis Korelasi Product Moment Pearson dengan bantuan program IBM SPSS Statistics 25 diperoleh $\mathrm{r}_{\text {hitung }}$ sebesar 0,730. Nilai $\mathrm{r}_{\text {tabel }}$ dengan jumlah $\mathrm{N}=65$ pada taraf kesalahan 5\% adalah 0,244. Dilihat dari perolehan harga $r$ diketahui bahwa $0,730 \geq$ 0,244 atau $r_{\text {hitung }} \geq r_{\text {tabel, }}$, dapat disimpulkan bahwa Ho ditolak dan Ha diterima sedangkan besar hubungan antara lingkungan sosial sekolah terhadap prestasi belajar IPS adalah 0,730 dan hal tersebut menunjukkan pengaruh yang kuat. Dengan demikian, terdapat hubungan yang signifikan antara lingkungan sosial sekolah dengan prestasi belajar IPS peserta didik SD Negeri 2 Parepare.

2) Pengujian Hipotesis Kedua

Berdasarkan hasil analisis Korelasi Product Moment Pearson dengan bantuan program IBM SPSS Statistics 25 diperoleh $\mathrm{r}_{\text {hitung }}$ sebesar -0,272. Nilai $r_{\text {tabel }}$ dengan jumlah $\mathrm{N}=65$ pada taraf kesalahan 5\% adalah 0,244. Dilihat dari perolehan harga $\mathrm{r}$ diketahui bahwa $-0,272<$ 0,244 atau $r_{\text {hitung }}<r_{\text {tabel }}$, dapat disimpulkan bahwa Ho diterima dan Ha ditolak sedangkan besar hubungan antara tingkat pendidikan orang tua dengan prestasi belajar IPS adalah -0,272, dan hal tersebut menunjukkan pengaruh yang sangat rendah. Dengan demikian, tidak terdapat hubungan yang signifikan antara tingkat pendidikan orang tua dengan prestasi belajar IPS peserta didik SD Negeri 2 Parepare.

3) Pengujian Hipotesis Ketiga

Besar hubungan antara lingkungan sosial sekolah dan tingkat pendidikan orang tua secara simultan terhadap prestasi belajar IPS yang dihitung dengan koefisien korelasi adalah 0,756. Hal tersebut menunjukkan pengaruh yang kuat sedangkan kontribusi secara simultan variabel lingkungan sosial sekolah dan tingkat pendidikan orang tua terhadap prestasi belajar IPS adalah $57,2 \%$ sedangkan $42,8 \%$ ditentukan oleh variabel yang lain. Selanjutnya diperoleh nilai probablitas (Sig. F Change) $=0,000$ di mana $0,000<0,05$, maka keputusannya adalah Ho ditolak dan $\mathrm{Ha}$ diterima. Dengan demikian, terdapat hubungan yang signifikan antara lingkungan sosial sekolah dan tingkat pendidikan orang tua dengan prestasi belajar IPS peserta didik SD Negeri 2 Parepare. 


\section{b. Uji Regresi Linear Sederhana}

1) Hubungan Lingkungan Sosial Sekolah dengan Prestasi Belajar IPS

Hasil output model summary untuk lingkungan sosial sekolah dengan prestasi belajar IPS menjelaskan bahwa besarnya nilai korelasi atau hubungan $(\mathrm{R})$, yaitu sebesar 0,730. Dari data tersebut diperoleh koefisien determinasi ( $\mathrm{R}$ Square) sebesar 0,532 yang mengandung pengertian bahwa hubungan lingkungan sosial sekolah dengan prestasi belajar IPS adalah $53,2 \%$.

2) Hubungan Tingkat Pendidikan Orang Tua dengan Prestasi Belajar IPS

Hasil output model summary untuk tingkat pendidikan orang tua dengan prestasi belajar IPS menjelaskan bahwa besarnya nilai korelasi atau hubungan (R), yaitu sebesar 0,272. Dari data tersebut diperoleh koefisien determinasi ( $\mathrm{R}$ Square) sebesar 0,074 yang mengandung pengertian bahwa hubungan tingkat pendidikan orang tua dengan prestasi belajar IPS adalah $7,4 \%$.

\section{c. Uji Regresi Linear Ganda \\ 1) Uji t}

Uji t bertujuan untuk mengetahui ada tidaknya pengaruh persial (sendiri) yang diberikan variabel lingkungan sosial sekolah dan tingkat pendidikan orang tua terhadap variabel prestasi belajar IPS.

Berdasarkan hasil output dapat diketahui

a) Pengujian hipotesis pertama untuk lingkungan sosial sekolah $\left(\mathrm{X}_{1}\right)$ terhadap prestasi belajar IPS (Y) diketahui nilai Sig $0.000<0.05$ dan nilai t hitung $8.496>t$ tabel 1.999 , sehingga dapat disimpulkan bahwa hipotesis pertama (Ha) diterima yang berarti terdapat hubungan yang signifikan antara lingkungan sosial sekolah dengan prestasi belajar IPS Peserta Didik SD Negeri 2 Parepare.

b) Pengujian hipotesis kedua untuk tingkat pendidikan orang tua $\left(\mathrm{X}_{2}\right)$ terhadap prestasi belajar IPS (Y) diketahui nilai Sig $0.019<$ 0.05 dan nilai t hitung $-2.399>\mathrm{t}$ tabel 1.999 , sehingga dapat disimpulkan bahwa hipotesis kedua $\left(\mathrm{H}_{0}\right)$ diterima yang berarti tidak terdapat hubungan yang signifikan antara tingkat pendidikan orang tua dengan prestasi belajar IPS Peserta Didik SD Negeri 2 Parepare.

\section{2) Uji F}

Uji $\mathrm{F}$ bertujuan untuk mengetahui ada atau tidaknya pengaruh simultan (bersama-sama) yang diberikan variabel lingkungan sosial sekolah dan tingkat pendidikan orang tua terhadap variabel prestasi belajar IPS.

Berdasarkan hasil output dapat dijelaskan bahwa nilai signifikansi untuk hubungan lingkungan sosial sekolah dan tingkat pendidikan orang tua secara simultan terhadap prestasi belajar IPS adalah nilai Sig $0.000<0.05$ dan nilai F hitung $41.444>F$ tabel 3.14. Sehingga dapat disimpulkan bahwa pengujian hipotesis ketiga (Ha) diterima yang berarti terdapat hubungan yang signifikan antara lingkungan sosial sekolah dan tingkat pendidikan orang tua dengan prestasi belajar IPS.

\section{Pembahasan}

\section{Hubungan antara Lingkungan Sosial Sekolah dengan Prestasi Belajar IPS Peserta Didik SD Negeri 2 Parepare}

Hasil penelitian menunjukkan bahwa terdapat hubungan yang signifikan antara lingkungan sosial sekolah dengan prestasi belajar IPS peserta didik SD Negeri 2 Parepare. Hal tersebut dibuktikan dari hasil analisis korelasi sederhana Pearson Product Moment diperoleh koefisien korelasi sebesar 0,730. Nilai $r_{\text {tabel }}$ dengan jumlah $\mathrm{N}=65$ pada taraf kesalahan $5 \%$ adalah 0,244. Hal ini menunjukkan bahwa $\mathbf{r}_{\text {hitung }}$ positif dan lebih besar dari $r_{\text {tabel }}(0,730 \geq 0,244)$. Dari data tersebut diperoleh koefisien determinasi ( $\mathrm{R}$ Square) sebesar 0,532 yang mengandung pengertian bahwa hubungan lingkungan sosial sekolah dengan prestasi belajar IPS adalah 53,2\%.

Hasil uji $\mathrm{T}$ menunjukkan bahwa nilai $\mathrm{t}$ hitung $8.496>\mathrm{t}$ tabel 1.999, sehingga dapat disimpulkan bahwa hipotesis pertama (Ha) diterima yang berarti terdapat hubungan yang signifikan antara lingkungan sosial sekolah dengan prestasi belajar IPS Peserta Didik SD Negeri 2 Parepare. Dari penjelasan tersebut dapat disimpulkan bahwa variabel lingkungan sosial sekolah dengan prestasi belajar IPS mempunyai hubungan positif dan signifikan. Dengan demikian dapat dikatakan bahwa jika semakin tinggi lingkungan sosial sekolah, maka prestasi belajar IPS akan semakin tinggi pula.

Hasil penelitian ini konsisten dengan teori yang dikemukakan oleh Slameto (2010) yang menggolongkan beberapa faktor yang dapat mempengaruhi belajar peserta didik menjadi dua, 
yaitu faktor intern dan faktor ekstern. Hasil penelitian menunjukkan bahwa faktor lingkungan sosial sekolah sebagai faktor eksternal yang mempengaruhi prestasi belajar peserta didik. Hasil tersebut didukung oleh penelitian Muhammad Faiz Muzakky (2015) yang berjudul "Pengaruh Self-Efficacy, Lingkungan Sosial dan Lingkungan Fisik Sekolah Terhadap Prestasi Belajar Ekonomi Siswa Kelas XII IPS MAN Babakan Tahun Ajaran 2015/2016".

\section{Hubungan antara Tingkat Pendidikan Orang Tua dengan Prestasi Belajar IPS Peserta Didik}

Hasil penelitian menunjukkan bahwa tidak terdapat hubungan yang signifikan antara tingkat pendidikan orang tua dengan prestasi belajar IPS peserta didik SD Negeri 2 Parepare. Hal tersebut dibuktikan dari hasil analisis korelasi sederhana Pearson Product Moment diperoleh koefisien korelasi sebesar -0,272. Nilai $\mathrm{r}_{\text {tabel }}$ dengan jumlah $\mathrm{N}=65$ pada taraf kesalahan $5 \%$ adalah 0,244 . Hal ini menunjukkan bahwa $\mathrm{r}_{\text {hitung }}$ negatif dan lebih kecil dari $\mathrm{r}_{\text {tabel }}(-0,272<$ 0,244). Dari data tersebut diperoleh koefisien determinasi ( $\mathrm{R}$ Square) sebesar 0,074 yang mengandung pengertian bahwa hubungan tingkat pendidikan orang tua dengan prestasi belajar IPS adalah $7,4 \%$.

Hasil uji $\mathrm{T}$ menunjukkan bahwa nilai $\mathrm{t}$ hitung -2.399 > t tabel 1.999, sehingga dapat disimpulkan bahwa hipotesis kedua $\left(\mathrm{H}_{0}\right)$ diterima yang berarti tidak terdapat hubungan yang signifikan antara tingkat pendidikan orang tua dengan prestasi belajar IPS Peserta Didik SD Negeri 2 Parepare.

Hasil penelitian ini konsisten dengan teori yang dikemukakan oleh Slameto (2010) yang menjelaskan bahwa faktor keluarga (ekstern) mempengaruhi prestasi belajar peserta didik. Jadi, dapat dikatakan bahwa tingkat pendidikan orang tua tidak selalu menjamin prestasi belajar anaknya. Hal tersebut bisa saja dipengaruhi oleh berbagai sebab misalnya faktor kesibukan atau ketidakmengertian orang tua dalam membersamai anaknya belajar atau faktorfaktor lain yang peneliti tidak menemukannya dalam penelitian ini.

Hasil tersebut didukung oleh penelitian dari Desi Wulandari (2015) yang berjudul "Pengaruh Tingkat Pendidikan Orang Tua Terhadap Prestasi Belajar Siswa Kelas V Di SDN Negeri 1 Jagoan Tahun Pelajaran 2014/2015". Hasil penelitian ini menunjukkan tidak adanya pengaruh antara tingkat pendidikan orang tua terhadap prestasi belajar. Dengan hasil perhitungan $\mathrm{t}_{\text {hitung }}<\mathrm{t}_{\text {tabel }}$ yaitu $0,549<2,074$ dan seberapa besar pengaruh antara tingkat pendidikan orang tua terhadap prestasi belajar siswa adalah $1,4 \%$.

\section{Hubungan antara Lingkungan Sosial Sekolah dan Tingkat Pendidikan Orang Tua dengan Prestasi Belajar IPS Peserta Didik SD Negeri 2 Parepare}

Hasil penelitian menunjukkan bahwa besar hubungan antara lingkungan sosial sekolah dan tingkat pendidikan orang tua secara simultan terhadap prestasi belajar IPS yang dihitung dengan koefisien korelasi adalah 0,756. Hal tersebut menunjukkan pengaruh yang kuat. Selanjutnya diperoleh nilai $R$ Square 0,572 yang berarti $57,2 \%$ merupakan kontribusi secara simultan antara variabel lingkungan sosial sekolah dan tingkat pendidikan orang tua dengan prestasi belajar IPS sedangkan 42,8\% ditentukan oleh variabel lain yang tidak dianalisis dalam penelitian ini.

Jadi dapat dikatakan bahwa makin baik lingkungan sosial sekolah maka akan makin tinggi prestasi belajar IPS peserta didik SD Negeri 2 Parepare. Namun hal tersebut berbeda dengan tingkat pendidikan orang tua bahwa ada beberapa peserta didik yang memiliki prestasi belajar IPS yang tinggi tidak terlahir dari orang tua yang memiliki tingkat pendidikan yang tinggi, begitupun sebaliknya.

Lingkungan sosial di sekolah yang baik akan membawa peserta didik untuk memiliki jiwa dan prestasi belajar yang baik pula. Peserta didik butuh pengakuan dari guru dan temantemannya sebagai sumber motivasi dalam belajar. Banyak peserta didik yang bergairah dan menampakkan aktivitas yang tinggi dalam belajar bukan karena memiliki motivasi berprestasi, tetapi karena sokongan sosial. Mereka menampakkan kegairahan dalam belajar jika mereka mempunyai hubungan sosial yang akrab dengan guru maupun dengan teman sekelasnya. Selain variabel lingkungan sosial sekolah, variabel tingkat pendidikan orang tua juga memberikan pengaruh kepada sebagian peserta didik dalam berprestasi di sekolahnya. Orang tua yang mempunyai tingkat pendidikan yang tinggi akan lebih percaya diri dalam memberikan bantuan pembelajaran dari sekolah kepada anaknya saat belajar. Berdasarkan uraian di atas maka dapat disimpulkan bahwa terdapat hubungan yang signifikan antara lingkungan 
sosial sekolah dan tingkat pendidikan orang tua dengan prestasi belajar IPS peserta didik SD Negeri 2 Parepare.

\section{SIMPULAN DAN SARAN}

Berdasarkan hasil penelitian dan pembahasan dapat ditarik kesimpulan sebagai berikut: (1) Terdapat hubungan yang signifikan antara lingkungan sosial sekolah dengan prestasi belajar IPS peserta didik SD Negeri 2 Parepare. Ditunjukkan dengan koefisien korelasi $\mathrm{r}_{\mathrm{x} 1 \mathrm{y}}$ sebesar 0,730 ( $\mathrm{r}_{\text {hitung }}$ sebesar $0,730>\mathrm{r}_{\text {tabel }} 5 \%$ sebesar 0,244) dan koefisien determinasi sebesar 0,532 yang berarti secara parsial ada $53,2 \%$ hubungan antara lingkungan sosial sekolah dengan prestasi belajar IPS peserta didik SD Negeri 2 Parepare; (2) Tidak terdapat hubungan yang signifikan antara tingkat pendidikan orang tua dengan prestasi belajar IPS peserta didik SD Negeri 2 Parepare. Ditunjukkan dengan koefisien korelasi $\mathrm{r}_{\mathrm{x} 2} \mathrm{y}$ sebesar $-0,272$ ( $\mathrm{r}_{\text {hitung }}$ sebesar $-0,272$ $<\mathrm{r}_{\text {tabel }} 5 \%$ sebesar 0,244) dan koefisien determinasi sebesar 0,074 yang berarti secara parsial ada $7,4 \%$ hubungan antara tingkat pendidikan orang tua dengan prestasi belajar IPS peserta didik SD Negeri 2 Parepare; (3) Terdapat hubungan yang signifikan antara lingkungan sosial sekolah dan tingkat pendidikan orang tua dengan prestasi belajar IPS peserta didik SD Negeri 2 Parepare. Ditunjukkan dengan $F_{\text {hitung }}$ sebesar 41,444 ( $\mathrm{F}_{\text {hitung }}$ sebesar 41,444 $>\mathrm{F}_{\text {tabel }} 5 \%$ sebesar 3,14), koefisien korelasi (R) 0,756 dan koefisien determinasi $(\mathrm{R})^{2}$ sebesar 0,572 yang

\section{DAFTAR RUJUKAN}

Hidayati, dkk. (2008). Pengembangan Pendidikan IPS SD. Jakarta: Direktorat Jenderal Pendidikan Tinggi Departemen Pendidikan Nasional.

Priyatno, Duwi. (2017). Panduan Praktis Olah

Data Menggunakan SPSS.

Yogyakarta: Penerbit ANDI.

Sapriya. (2017). Pendidikan IPS Konsep dan Pembelajaran. Bandung: PT Remaja Rosdakarya.

Slameto. (2010). Belajar dan Faktor- Faktor yang Mempengaruhi. Jakarta: Rineka Cipta.

Sugiyono. (2017). Statistika untuk Penelitian. Bandung: Alfabeta.

Sukmadinata, Nana Syaodih. (2007). Landasan Psikologi Proses berarti secara simultan ada 57,2\% hubungan lingkungan sosial sekolah dan tingkat pendidikan orang tua dengan prestasi belajar IPS peserta didik SD Negeri 2 Parepare.

Berdasarkan kesimpulan yang telah dikemukakan tersebut, maka ada beberapa saran yang perlu peneliti kemukakan sebagai rekomendasi dalam peneliti ini, yaitu: (1) Guru diharapkan untuk lebih memperhatikan prestasi belajar peserta didik dengan mengoptimalkan kemampuannya dalam mengelola pembelajaran, menciptakan suasana belajar yang nyaman dan aktif sehingga menimbulkan prestasi belajar IPS peserta didik meningkat; (2) Orang tua hendaknya selalu memotivasi dengan selalu memberikan nasihat dan memantau anaknya dalam hal belajar dan memberikan arahan tentang pendidikan bagi anaknya. Orang tua sebaiknya juga selalu memberikan dukungan yang dapat berupa fasilitas belajar dan bisa juga secara nonmaterial pada anaknya untuk selalu beprestasi; (3) Sekolah secara rutin melakukan pengawasan dalam pelaksanaan pembelajaran sehingga tercapai kegiatan belajar mengajar yang menjadikan siswa memiliki minat yang tinggi dalam rangka meningkatkan prestasi belajar IPS siswa; (4) Saran bagi peneliti selanjutnya. Penelitian ini memberikan informasi bahwa bukan hanya variabel lingkungan sosial sekolah dan tingkat pendidikan orang tua yang mempunyai hubungan dengan prestasi belajar IPS peserta didik, tetapi masih banyak variabelvariabel yang lain.

Pendidikan. Jakarta: PT. Remaja Rosdakarya.

Tu'u, Tulus. (2004). Peran Disiplin pada Perilaku dan Prestasi Peserta didik. Jakarta: Grasindo.

Muzakky, Muhammad Faiz. (2015). Pengaruh Self-Efficacy, Lingkungan Sosial dan Lingkungan Fisik Sekolah terhadap Prestasi Belajar Ekonomi Siswa Kelas XI IPS MAN Babakan Lebaksiu Tahun Ajaran 2014/2015.

Sandrawati F, Indira. (2016). Pengaruh Lingkungan Sosial Siswa dan Kondisi Ekonomi Orangtua Terhadap Prestasi Belajar Siswa Di SMP Negeri 9 Kota Probolinggo. Jurnal Penelitian dan Pendidikan IPS (JPPI), Vol.10 No.2 (2016) 245260. 
Wulandari, Desi. (2015). Pengaruh Tingkat Pendidikan Orang Tua terhadap Prestasi Belajar Siswa Kelas V di SD Negeri 1 Jagoan Tahun Pelajaran 2014/2015.

Departemen Pendidikan Nasional. (2003). Undang-Undang RI Nomor 20 Tahun 2003 tentang Sistem Pendidikan Nasional. Jakarta: Dikmenum. Depdiknas.

Departemen Pendidikan Nasional. (2008). Kurikulum 2013. Jakarta: Dikmenum. Depdiknas.

Departemen Pendidikan Nasional. (2010). Peraturan Pemerintah RI No. 17 tahun 2010 tentang Pengelolaan dan Penyelenggaraan Pendidikan. Jakarta: Dikmenum. Depdiknas.

Departemen Pendidikan Nasional. (2016). Peraturan Menteri Pendidikan dan Kebudayaan RI No. 23 tahun 2016 tentang Standar Penilaian Pendidikan. Jakarta: Dikmenum. Depdiknas. 